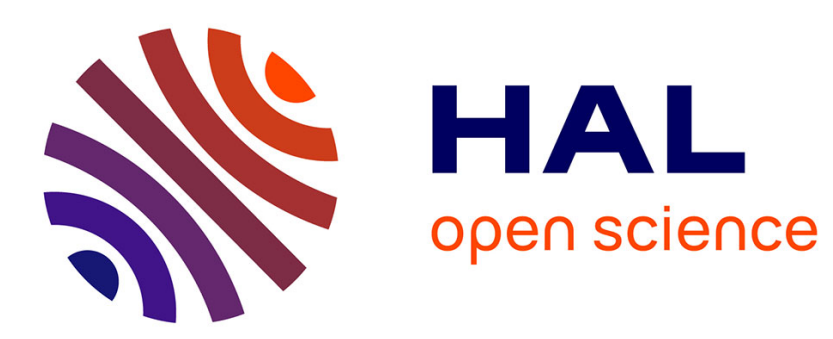

\title{
Reconciling the new demands for food protection with environmental needs in the management of livestock wastes
}

\author{
C.H. Burton
}

\section{- To cite this version:}

C.H. Burton. Reconciling the new demands for food protection with environmental needs in the management of livestock wastes. Bioresource Technology, 2009, 100 (22), p. 5399 - p. 5405. 10.1016/j.biortech.2008.11.018 . hal-00504213

\section{HAL Id: hal-00504213 \\ https://hal.science/hal-00504213}

Submitted on $20 \mathrm{Jul} 2010$

HAL is a multi-disciplinary open access archive for the deposit and dissemination of scientific research documents, whether they are published or not. The documents may come from teaching and research institutions in France or abroad, or from public or private research centers.
L'archive ouverte pluridisciplinaire HAL, est destinée au dépôt et à la diffusion de documents scientifiques de niveau recherche, publiés ou non, émanant des établissements d'enseignement et de recherche français ou étrangers, des laboratoires publics ou privés. 


\section{Reconciling the new demands for food protection with environmental needs in the management of livestock wastes}

\section{Colin H Burton}

Cemagref, Groupement de Rennes, 17, avenue de Cucillé, 35044 Rennes, France +33 (0) 223.48.21.21 (tel) +33 (0) 223.48.21.15 (fax) colin.burton@cemagref.fr

Government policy in many countries has been to promote manure management methods to reduce the negative impacts related to water and air pollution. The central strategy of encouraging manure as a fertiliser rather than treating it as a waste, is under threat from new concerns on public health and especially food quality. Restrictions on manure applications to certain food crops and the stipulation of treatment to $70^{\circ} \mathrm{C}$ for one hour (in the case of manure products) represent barriers to the use of such material as a useful organic product in the farming and horticultural industries. However, the sensible development of spreading plans in which high and low risk land is identified can enable appropriate and effective treatment for each situation and minimise overall cost. In the high risk situations, processes based on heat treatment remain the most reliable but there still remains the need to ensure a minimum temperature to ensure a satisfactory treatment. Direct application of heat available from biogas coupled with heat recovery may make thermal treatment of effluents a viable option where no effective environmental friendly alternatives exist.

\section{Introduction}

In the current management of livestock wastes, there are certain key objectives that can be grouped under three headings - (a) farm operation, (b) nuisance and (c), environmental pollution.

(a) Issues relating to an efficient and economic farm operation - these relate primarily to manure handling problems, including the methodical removal from farm buildings, subsequent storage and the organised disposal via land spreading. Poor manure management systems can result in excessive demands on staff time and equipment with the resulting higher costs of animal production. Related new technologies include farm building flushing systems, mixing and separation (to make the handling of liquids easier), improved design of stores and land spreading equipment.

(b) Issues relating to odour and other nuisance - these are often the primary source of complaint being more readily identified than long term threats to the environment. The corrective action taken is either revised management practices such as timing or method of land spreading, or the introduction of a treatment regime such as aeration or the use of odour-suppressing chemicals. Due to the difficulties in evaluating offensive odours, the implementation of certain specific measures, even if not completely effective is often an acceptable solution. Other nuisances impacting on neighbours such as noise and visual impact may require changes to the farm operation. 
(c) Issues relating to water and air pollution - these include water contamination from the effluent both direct and indirect (from soil leaching of nitrates or phosphates) and emissions of ammonia, nitrous oxide and methane. Some of these impacts can result from the poor utilisation of nutrients in which case measures such as manure management plans may help. However, where there are local or regional excesses of manure nutrients, especially $\mathrm{P}$ or $\mathrm{N}$, some form of treatment is required with the removal of surpluses from the farm area.

More recently, a further demand from the management of livestock wastes has become of importance; that relating to hygienic issues resulting from the pathogens invariably present in animal manures (Figure 1). In fact a series of issues concerning hygiene issues over the last 20 years has brought this to light including drinking water contamination (Guan and Holley, 2003), crop contamination (Nicholson et al, 2005) and the spread of animal disease (Thompson et al, 2002). The net effect of these has been to raise doubts on some of the uses of manure and in consequence, to limit some of the established options for meeting environmental targets.

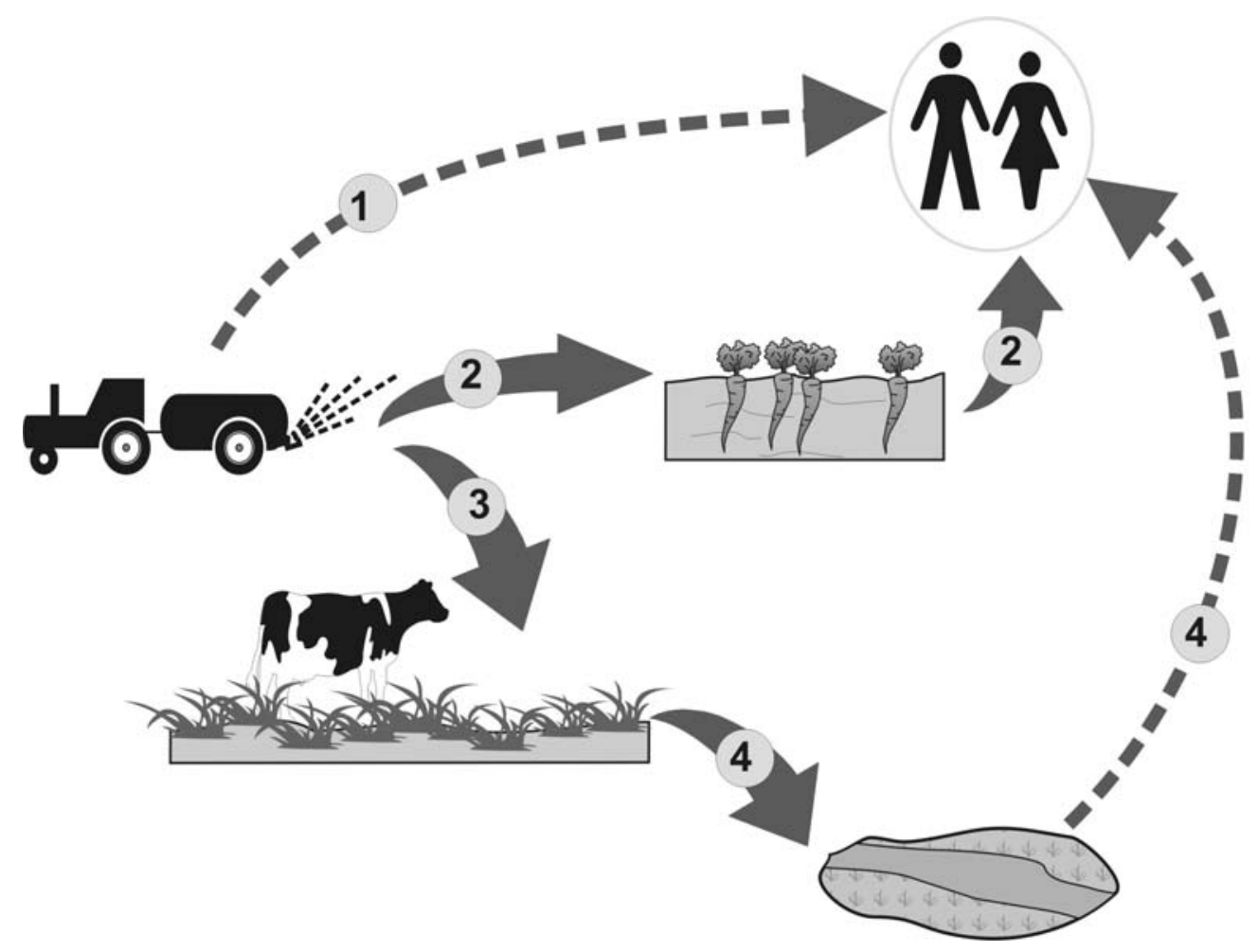

Figure 1: potential health impacts from the handling and land application of livestock manure. 1. direct transfer of zoonotic agents to farm staff and people nearby; 2. contamination of food crops; 3 . spread of disease via pasture; 4 . contamination of surface water.

In addressing these health concerns, the approach of this paper has been first to establish the nature and extent of the four main hygienic risk categories. In the subsequent section, the main technologies for managing farm wastes to improve environmental protection are set out. The two sets of needs are contrasted in section 4 and possible ways forward given in the following section ahead of conclusions. 


\section{Food safety and public health fears linked to organic wastes}

\subsection{Disease risks to farm animals}

Although the potential spread of zoonotic diseases to people will always cause the greatest concern, it is disease amongst livestock that represents by far the largest number of confirmed cases of illness. Within the farm, the transfer of disease via manure or buildings are easily understood but there is an additional dimension in the case of grazing animals and land spreading on grassland (Stacey et al, 2007). In this case, there is a real risk of transferring the disease to neighbouring farms. However, unlike the general threat to food safety caused by the ubiquitous presence in manure of pathogens such as salmonella or e-coli, most of the main animal diseases pathogens of concern are only rarely present. Nonetheless, in the case of a disease outbreak amongst farm animals, the manure and related effluents are often a principle vector for transfer and in the absence of good bio-security and good waste management there is a much increased rate of spread. In the event of an outbreak of a notifiable disease at a livestock farm, national regulations are usually both precise and mandatory covering both farm procedures, livestock slaughter and the disposal of any waste material collected or already in store which must be deemed contaminated. Once the farm or local area is de-contaminated and declared "clean”, any special measures used may be stopped.

\subsection{Contamination of food crops.}

Clearly there has to be a difference between the rigorous application of effluent treatment in times of a specific animal disease outbreak and that of the sustainable but reduced measures to address to the continuous presence of a range of zoonotic pathogens. However, there is certainly published evidence of food crops contaminated by pathogens (eg: Evans et al, 2003, in the case of campylobacter) and in some cases this is linked to the use of animal manures as a fertiliser (eg: Ackers et al, 1998, in the case of Escherichia coli $\mathrm{O} 157$ : H7). The number of cases remains relatively small but the perceived risk from the retailers and the general public is leading to increasing restrictions of such manure use. It might be noted that avoidance of land spreading manures on certain vegetable crops will be no guarantee that they will not be contaminated from other environmental sources such as wild animals or birds (Tyrell et al, 2004). One might add that there may be equal or greater concerns over the practice of irrigating river water onto food crops in that rivers are frequently identified as a disease transfer vector. Clearly though, the application of manures to any food crops that may be consumed raw can only increase the risk of contamination from a range of common pathogens such as salmonella or campylobacter. The issue is that, despite the organic credentials, there may be increasing reluctance to apply untreated manures to a much wider range of vegetable crops including those for which there is little evidence of contamination. Separately, there are also fears that the pathogen load from applied manures can reach and contaminate inshore seafood production via the river system (Laszlo, 2003).

\subsection{Contamination of water supplies}

There have been several well-reported cases of drinking water becoming contaminated by effluents from livestock agriculture resulting with the serious illness of local people 
such as the incident at Walkerton, Canada (Ali, 2004)). Such events are mercifully rare and often the result of accidental discharge. However, it is all too apparent that manures can easily enter surface waters adding a large bacterial load to the system - eg: by the run-off especially if heavy rainfall follows land applications. Various methods can be proposed for better management of land spreading practice to protect rivers and streams but in some high risk areas this may not be considered enough and the farmer may find himself with greatly restricted options. If water quality is likely to be effected, the reaction of local people and in consequence, politicians, can be expected to be very determined and restrictive measures on manure use may well follow.

\subsection{Direct risk to farm staff and people nearby.}

The perceived health risk with respect to people in close proximity to manure is likely to be much higher than the actual quantified risk. The fear of illness associated with manures is logical and widespread but there have been few verified cases of illness as a result of this route. Farm staff in regular close proximity with animals are at highest risk but this can also be the result of the internal environment of the animal buildings (eg: dust inhalation, high ammonia concentrations etc) as much as from a direct infection from the waste materials present. Furthermore, the recent cases of avian flu generating illness in local people (Lahariya et al, 2006) can only emphasise this dimension of the problem and farm hygiene and bio-security at least will need to be reviewed. Beyond the farm, the main impact on local people will be via the land spreading practice and the aerosols sometimes produced as a result. The fact that this can cause an odour nuisance is not disputed but this should not be confused with an exposure to an infective dose of a zoonotic disease. Nonetheless, public fears evoked from offensive odours can quickly raise questions on health. The association of odour and any ill health is easily made but difficult to disprove : scientific reasoning based on risk analysis and microbiological procedures are both difficult to explain. Sound argument alone may not be enough to resolve such concerns which demand straightforward "black and white” reassurances.

\section{Current waste management technologies meeting environmental criteria}

\subsection{Farm based measures}

Manure management systems for the livestock farm fall into three main areas, collection within the building, the means of removal and subsequent external storage. The selective use of litter or bedding for animals is generally considered a means for reducing ammonia emissions (Groenestein et al, 2006), a benefit increased by the addition of certain absorbents including zeolites (Amon, 1997). However, solid manure systems are not popular owing to greater labour and equipment demands in the subsequent manure handling operation.

Storage of slurries below the animal pens (especially for pig production) can contribute to a wide range of emissions especially during the agitation often necessary prior to emptying. Consequently, there is a clear benefit of more frequent removal of manure in improving the conditions for the animals which can extend to reduced overall emissions to the wider environment. To that end, regular manure collection enabled by automated mechanical scrapers or flushing systems both meets animal welfare and environmental 
concerns at the local level. Acidification of cleaning wastewaters can further reduce ammonia emission.

Longer term storage whether inside or external to buildings is a crucial factor in good management in enabling a wide window for land application and thus targeted use at appropriate times. Many countries now specify minimal storage capacity to this end (Burton and Turner, 2003). Storage itself can enable some reduction in certain pathogens especially in warmer conditions (Mitscherlich and Marth, 1984). However, the benefit of this abatement procedure can only be realised once additions of fresh manure to the store are stopped which otherwise can continue to add new doses of pathogenic agents.

\subsection{Land application procedures}

The cornerstone of most manure management schemes is the application of the various materials to fields as a means of fertilising growing crops. Guidelines in many European countries encourage this approach, the series of booklets on managing livestock manures from MAFF in the UK (Chambers et al, 2001) are typical. Equipment and methodology for land application have been the subject of research for over 30 years resulting in the development of systems enabling precise and even applications with reduced emissions of ammonia and odour. Research advanced further in the late 1990's with the development of in-line analysers set up on slurry tankers (illustrated in Figure 2) to enable applications closer to crop needs (Scotford et al, 1999).

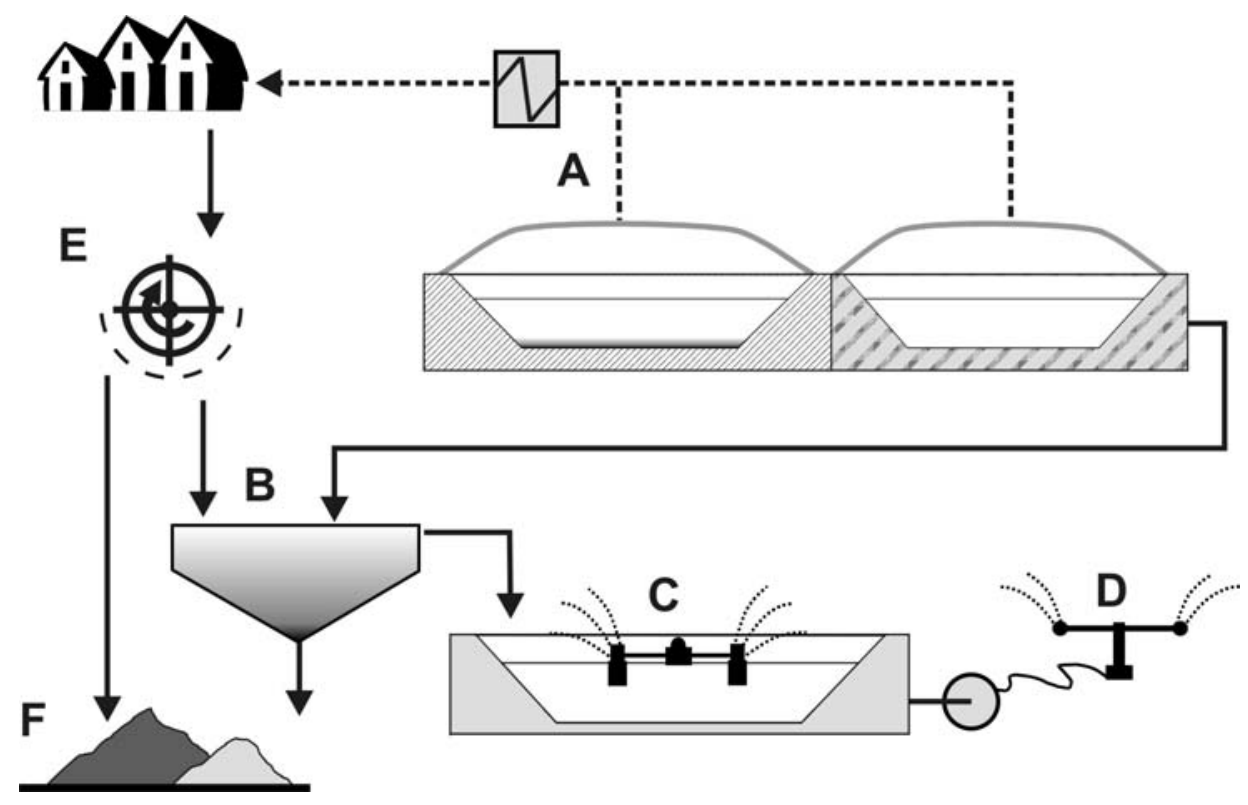

Figure 2: advanced manure application including integrated analyser to estimate phosphorous and nitrogen content based on the measurement of specific density. The same equipment includes injection tines (right) to reduce emissions .

In parallel to farm equipment development has been a trend to encourage manure management plans that seek to target fields that can safely receive defined quantities of manure at certain times of the year; identified excesses need to be exported. The development of such protocols such as represented by the MANNER software 
(Chambers et al, 1999) enables farmers more easily to estimate quantities of manure to apply to given crops. (This concept has been set in regulation in the Netherlands requiring livestock farmers to follow an accounting system for nutrient management (Ondersteijn et al, 2002). Intelligent land spreading systems using GPS to locate the tractor position along with supplied data on crops and field layout can enable the application of precise amounts of manure to the crop (Carton and Lenerhan, 1998) thus enabling greater reliability in the procedure. The overall direction of such developments is potentially a balanced and sustainable farming system with a neutral impact on the environment.

\subsection{Treatment options}

Even with the best land application plans for manure, there may remain demands for treatment to deal with specific hazards or simply to reduce the excesses revealed in relation to the local environmental capacity. Over the last 30 years a large amount of work has been published on treatment systems for livestock wastes (Burton and Turner, 2003). The consequence is the availability of treatment systems that can deal with many of the environmental problems of manure that can not be easily resolved by farm management or land application alone. Some of these systems are in operation in parts of Europe including anaerobic digestion in Germany (Cameron, 2007), removal of nitrogen in France (Beline et al, 2004), acidification in Denmark (Eriksen and Sorensen, 2006) and widespread use of separation and composting systems. Other technologies such as evaporation and drying currently remain confined to research farms. The benefit of these individual systems as summarized in Table $\mathbf{1}$ is not universal, each impacting on one or more components alone although combined systems can potentially remove most of the environmental consequences but at a financial cost (Vanotti et al, 2007).

Table 1. The relative contributions of the main treatments in the reduction of specific effluent components. ++ expected large effect; + some benefit; ? little or no benefit; !! possible negative effect. * Aeration process including nitrification and de-nitrification

\begin{tabular}{lccccccc}
\hline Process & \multicolumn{7}{c}{ Effect of treatment on the reduction of: } \\
& TSS & BOD $_{5}$ & Odour & Kj-N & Am-N & P & K \\
\hline Mechanical screening & + & $?$ & $?$ & $?$ & $?$ & $?$ & $?$ \\
Sedimentation & ++ & $?$ & $?$ & + & $?$ & + & $?$ \\
Precipitation (lime) & + & $?$ & $?$ & $?$ & $! !$ & ++ & $?$ \\
Aeration* & $?$ & ++ & ++ & + & ++ & $?$ & $?$ \\
Thermophilic aeration & $?$ & + & ++ & $?$ & $! !$ & $?$ & $?$ \\
Anaerobic digestion & $?$ & ++ & ++ & $?$ & $?$ & $?$ & $?$ \\
Acidification & $?$ & $?$ & $?$ & $?$ & ++ & $?$ & $?$ \\
Ammonia stripping & $?$ & $?$ & $?$ & + & ++ & $?$ & $?$ \\
Evaporation \& drying & ++ & + & + & + & $?$ & ++ & $?$ \\
\hline
\end{tabular}


A typical treatment scheme based on covered lagoons is illustrated in Figure 3. The biogas itself has little effect on the nutrient content but the value of the energy produced often justifies the investment and may enable some financial support. Of special importance are the separation process and sludge collection with the production of an exportable compost or organic product that enables the export of excess phosphorous. Likewise, the final aeration stage can enable the removal of unwanted surplus nitrogen (as di-nitrogen gas) leaving a reduced nutrient load that more closely fits the capacity of the local environment. Irrigation of a final dilute effluent via pipeline requires less staff time and has environmental credentials in avoiding the need for road haulage but care must be taken not to overdose the fields used.

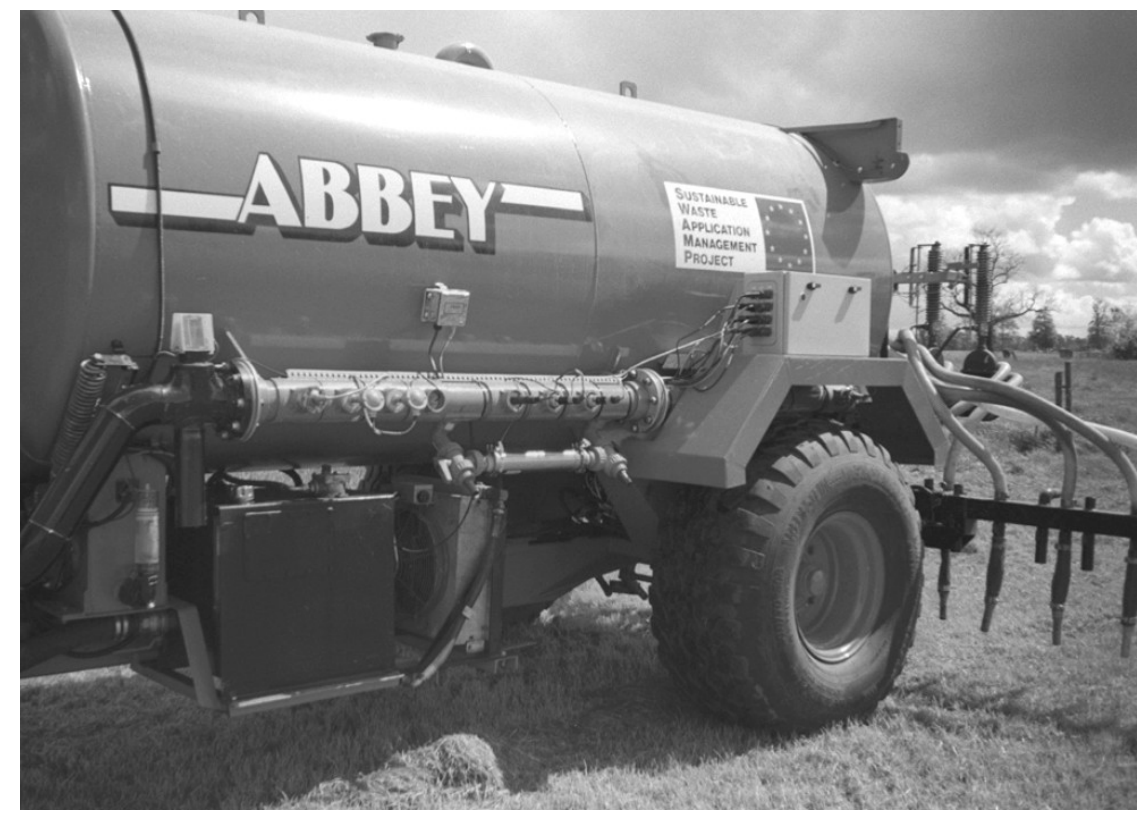

Figure 3: a treatment scheme for liquid manure based around a biogas unit with the production of electricity. A - covered lagoons with biogas or electricity produced used locally; B - clarification and aeration (C) of digestate; D - irrigation onto local land; E - optional separation of solids and F, formulation as an exportable product.

\section{The potential conflict areas between health and environment criteria}

\subsection{Responding to outbreaks of notifiable diseases}

The over-riding need to eliminate disease agents from animal stock and the environment often leads to temporary measures that pay little respect to the environment. All too evident during the Food and Mouth outbreak in the UK in 2001 was the burning and burial of huge numbers of slaughtered carcasses in open pits with the resulting emission both air and groundwater as well as social impacts (Jones et al, 2004; Mepham, 2001). Alternative more environmentally-friendly measures for tackling such outbreaks remain a subject for research (Cumby et al, 2005) but the predominance of the large scale use of chemical sanitizer is likely to remain. This is especially the case in dealing with the large volumes of associated farm effluent which must in most cases be considered as contaminated by the pathogen. The application of a disinfectant, even in large volumes, represents in most cases an easily verified process that can be very effective; however, its impact on the wider environment remains poorly understood. 
Although the complete ban on the application of livestock manures on food crops is not yet on the political agenda, some initial movement in this direction has already started with restrictions in some countries on the use of manure on certain food crops especially those consumed raw. The origins of such moves are the existing controls on the application of sewage sludge; manures are increasingly considered to present similar risks. However, the greater pressure is likely to come sooner from commercial sectors with the major buyers of food stipulating limited or no application of animal wastes on certain crops. The consequence is initially difficult to measure but with many pig and poultry farms concentrated in areas where there is already insufficient crop land to safely accept the manures produced, the surplus volumes can only become greater. Thus, returning to environmental concerns, such restrictive measures on land spreading can only accentuate the threat from nutrient surpluses as set out in Figure 4.

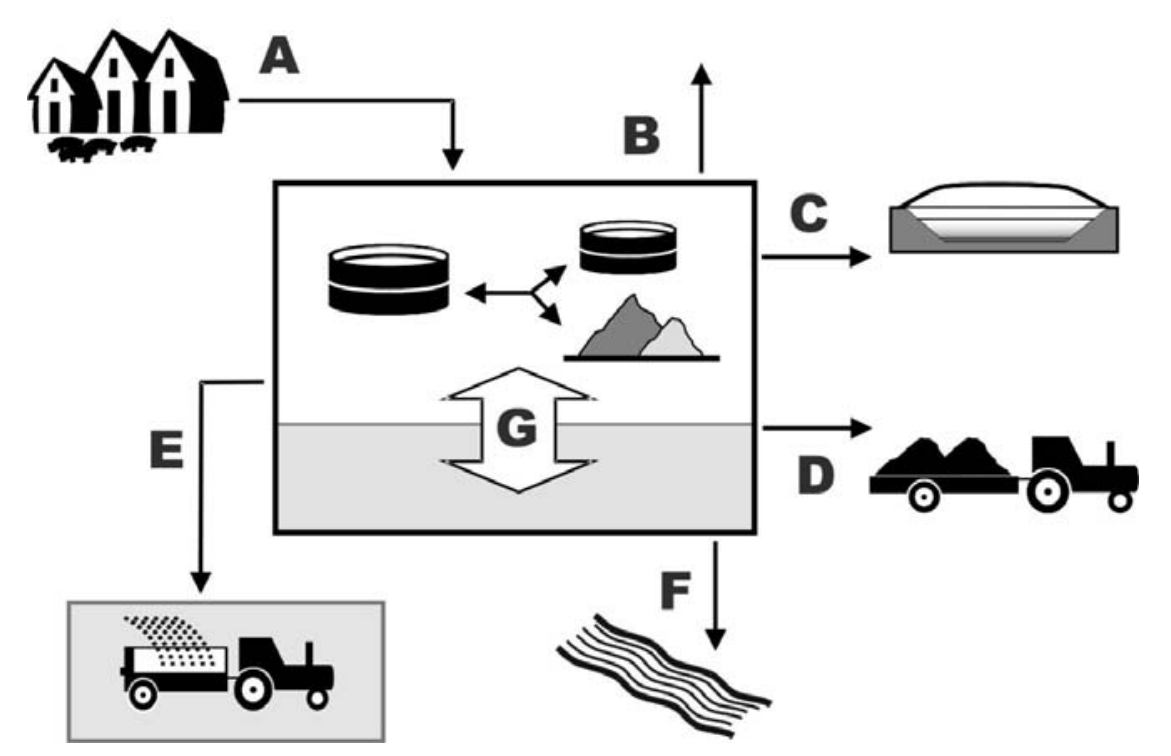

Figure 4: mass balance concept as applied to a livestock farm. Most of the animal food brought in will leave as waste products from the farm some of which will be lost by emissions. The remainder can be stored (limited), exported, removed by treatment, land spread or lost to the environment as pollution.

Exporting manure surpluses out of the local area is a limited option often requiring preconcentration and some form of treatment to meet environmental and hygiene requirements. It applies easiest to solid fractions although pipeline movement of liquids remains an option. In all cases, the costs rise with the distances involved which themselves increase as the area of available local land is reduced.

\subsection{Development of legislation on manure management}

The handling and disposal of livestock manure is increasingly subject to national and European legislation aimed at protecting both the environment and public health. In most of Europe, there are national regulations that specify when, where and how manures can be spread; for the most part these are aimed at maximizing crop uptake and thus avoiding losses of nutrient resulting in water pollution. At the European Union level, there are a serious of directives that impact on manure management as summarised in Table 2. 
Table 2: main European regulations affecting the development of national legislation controlling manure use and disposal.

\begin{tabular}{|c|c|c|}
\hline Reference & $\begin{array}{l}\text { Common } \\
\text { name }\end{array}$ & Impact on livestock agriculture \\
\hline 86/278/EEC & $\begin{array}{l}\text { Sewage Sludge } \\
\text { Directive }\end{array}$ & $\begin{array}{l}\text { Aimed at sewage sludge with limitations on use of land for } \\
\text { vulnerable food crops and maximum levels of certain } \\
\text { pathogens: potential use as a precedent for similar measures for } \\
\text { livestock wastes. }\end{array}$ \\
\hline 91/271/EEC & $\begin{array}{l}\text { Urban } \\
\text { Wastewater } \\
\text { Directive }\end{array}$ & $\begin{array}{l}\text { Aimed at waste water with the inclusion of set limits for the } \\
\text { presence of certain pathogens: potential use of same limits for } \\
\text { livestock wastes. }\end{array}$ \\
\hline 91/676/EEC & $\begin{array}{l}\text { Nitrate } \\
\text { Directive }\end{array}$ & $\begin{array}{l}\text { Limits application of total nitrogen in form of animal manures } \\
\text { to } 170 \mathrm{~kg} \text { per hectare per year in areas defined as nitrate } \\
\text { vulnerable. No equivalent limit for separate application of } \\
\text { chemical fertiliser. }\end{array}$ \\
\hline 96/61/EC & IPPC Directive & $\begin{array}{l}\text { Licensed pig and poultry farms must use "best available } \\
\text { technology” in meeting environmental obligations. Cattle not } \\
\text { yet included. Measures currently based around measures for } \\
\text { good handling and land application of manures. }\end{array}$ \\
\hline $1774 / 2002$ & $\begin{array}{l}\text { Animal By- } \\
\text { Products } \\
\text { Regulations }\end{array}$ & $\begin{array}{l}\text { Far-reaching controls on the use of all animal wastes but aimed } \\
\text { mostly at the meat processing and rendering industries. } \\
\text { Classification of all manures as "category 2" requires treatment } \\
\text { at } 70 \text { deg.C for one hour unless spread at the farm as raw } \\
\text { manure. }\end{array}$ \\
\hline
\end{tabular}

At the present time, it is the Animal By Products Regulations (ABPR) that have the greatest impact on manure management in terms of measures to protect food safety and health. The origin of the often-cited temperature time criterion $70^{\circ} \mathrm{C}$ for one hour is unclear as it is excessive for certain pathogens and insufficient for others but it has become an accepted bench mark for establishing minimal treatment. The original regulation is in fact even more demanding in specifying both (a) closed system and (b) particles no larger than $12 \mathrm{~mm}$, both of which would effectively rule out composting using conventional windrows. However, there appears to be some room for developing equivalent treatments: on this basis proposals have been made of lower temperatures $\left(60^{\circ} \mathrm{C}\right.$ ), larger particles (up to $40 \mathrm{~mm}$ ) and a windrow system but for a longer time period of 8 days (DEFRA, 2004). This idea of equivalent systems is developed in later amendments (208/2006) but the extent of flexibility in process terms (temperature, exposure time etc.) is not clear. Strangely enough, raw manure is exempt from the regulation although there is no particular evidence that it presents a lower risk than partdigested or part-composted material. Further amendments may yet be made but the 
precedent is already well established: the export of manure products intended for land application not meeting the standards set will become increasingly difficult to accomplish if not impossible.

\section{Strategies to reconcile environment and health concerns}

\subsection{Measures relating to control of land application}

Research back in the 1970's established then that the presence of certain harmful bacteria in the environment following land spreading was limited to a period of time and rarely more than a few months in most cases (Mitscherlich and Marth, 1984). Jones (1980) reported a die off by $90 \%$ of salmonella over 2 to 4 weeks of storage and rapid decline following land application of cattle slurry to pasture. The persistence of many pathogens in the environment is reduced by the simple exposure to air and sunlight because oxygen, ultra-violet light and drying all contributing to the rapid fall in numbers (Burton and Turner, 2003). The process of declining numbers is accelerated in warmer climates but conversely, some pathogens (especially those forming spores) can persist many months in winter conditions.

In consequence, the spreading of fresh manure is rarely encouraged, the strategy of storage prior to land spreading clearly enabling some hygienic benefits. Storage is also an advantage in meeting environmental objectives by enabling targeted land application but it is crucial to stop all manure additions several weeks before commencing the land spreading campaign to gain the full hygienic benefit of the process. The lack of long term persistence of pathogens in the environment has enabled guidelines around the principal of application of livestock manures a minimum of several months before harvesting certain at risk food crops: in the UK, the FSA proposes 6 months before planting and 12 months before the final harvesting for "ready to eat" crops (Hickman et al, 2005). This approach is already encompassed in the disposal of sewage sludge in the UK where crop type, sludge origin and time periods are included in the overall strategy known as the "Safe Sludge Matrix" (Desmier, R., 1999). More generally, one would expect manures to be preferentially applied to land used for none food crops, if available : with the increased area for energy crops, the opportunity to safely apply at least some of the animal wastes in a balanced way will increase.

\subsection{The role of treatment in reducing pathogen risks}

The strategy of minimum storage and targeted application to specific crops well before harvesting is only likely to be part of the solution. Increasingly, one can expect the demand to meet set hygienic standards given as maximum counts of specified organisms, although in many cases, the problems of representative sampling and extraction makes this difficult. Quotable standards do already exist in relation to compost products. The French standards NFU 44051 (composts including pig manure) and NFU 42001 (composts based on poultry droppings) both set maximums for e-coli $\left(10^{2}\right.$ to $10^{4}$ per gram), enterococci $\left(10^{2}\right.$ to $10^{4}$ per gram), clostridium perfringens $\left(10^{2}\right.$ to $10^{3}$ ), salonella (below detection) and listeria monocytogenes (below detection) amongst pathogens and faecal indicators - the lower values apply to products aimed at market gardening (Levasseur and Dutreme, 2007). Similar standards exist in most European countries as reviewed by Brinton (2000). Of special significance are the standards in 
the ABPR given as $10^{3}$ to $10^{4}$ per gram of e-coli or entereococci and an absence of salmonella in 25 gram samples. Its doubtful that even a poor composting or digestion procedure would ever increase the numbers of pathogens, the mere concept of storage implying some benefit but once the treatment is chosen, the set standards become binding.

The reduction of pathogens in manure by various treatments has been well reported over recent years (Burton and Turner, 2003) including reductions by one or more log-10 units resulting from aerobic and anaerobic digestions, composting, the use of lime and any prolonged process not involving back mixing. Cote et al (2006) report a fall of between 1 and 3 log-10 units of total coliforms and e-coli following low temperature anaerobic digestion. Vanotti et al (2005) saw a progressive removal of salmonella through a combined treatment with up to 1 log-10 unit following separation, 2 to 3 after a cyclic aeration-anoxic treatment and below detection following a final $\mathrm{pH}$ increase to 10 to aid phosphate removal. More recently, work by Pourcher (detailed by Burton et al, 2007) tracked the decline in e-coli, enterococci and spores of clostridium perfringens in separated manure samples as a function of temperature which is deemed the principle factor in a composting operation. With an exposure of substrate to $55^{\circ} \mathrm{C}$, there was a reduction of 2 to $3 \log -10$ units even after one hour : this decline approached complete elimination after 24 hours. The spores were the most temperature resistant but no detectable bacteria remained after being held for 72 hours at $70^{\circ} \mathrm{C}$.

\subsection{Thermal treatment options to guarantee set hygiene standards}

In their review on disinfection techniques for manures inoculated with specific viruses, Turner and Burton (1997) concluded that thermal treatment or the application of a process that implies heating represents the most effective measure in removing a health risk other than the use of large amounts of chemical disinfectant. In continuous pilot scale trials in which animal viruses were added to manure, Turner et al, (1998 and 1999) demonstrated inactivation by over 4 log-10 units (or to below detection) by the rapid application of heat. For some viruses, temperatures as low as $53^{\circ} \mathrm{C}$ could be sufficient with exposure a matter of mere minutes. This same study demonstrated heat recovery in excess of $80 \%$ allowing energy costs below one euro per tonne.

Clearly, the source of heat is not likely to be critical hence a similar benefit may be expected from an exothermic biological process producing elevated temperatures. The limitation lies with the difficulty in achieving and maintaining even the lower end or the required temperature range: as temperatures rise, microbial activity is progressively retarded at the same time as heat losses will increase. The result is the ceiling of 60 or $70^{\circ} \mathrm{C}$ experienced in many composting systems. The problem is further aggravated by the development of cold zones in the processes media: Cronje et al (2003) used trace heating to sustain compost in a closed reactor at 60 to $70^{\circ} \mathrm{C}$ but found the base where air entered was at least 10 deg.C cooler. In the case of windrow composting, the external layers can be expected to be much cooler than the core. Arguably, frequent turning can reduce this effect with transfer of all material at some point to the hot zone although there may remain doubts that some degree of cross contamination may have occurred.

The difficulty of measuring pathogen numbers in manures and manure products (especially solids), is likely to lead to greater dependence on defining and monitoring conditions of treatment as a means of establishing a sanitised product. The ABPR has 
already clearly set this out in the required $70^{\circ} \mathrm{C}$ for one hour as one criterion for adequate treatment. In response to this, one can foresee the combination of exothermic biological treatments followed by supplementary heat application to ensure that the temperature-time criteria have been respected. In the case of effluents, a final heat application may be enabled without buying in energy by the use of biogas produced in a separate step as proposed by Burton (2007). Heat recovery in any case can greatly reduce energy requirements.

\section{Conclusions}

- New demands on manure management to meet food quality and health concerns will have to be met but without compromising environmental objectives. For most of the livestock wastes produced, the final use must continue to be the application to growing crops to enable nutrient recycle and to avoid the same components from otherwise becoming a source of pollution.

- The best strategy is to apply as much material as possible to locally available land with low risk crops. Applications to animal pasture represent the second option but grazing should not be resumed sooner than 2 to 4 weeks which would also allow some re-generation of the grass sward. Once the capacity of such convenient land is used up, further volumes of manure might be applied to land with medium risk crops such as cereals or root vegetables but only having observed a minimum storage of 1 to 2 months.

- For the manures that need to be applied to land used for the high risk crops such as "ready to eat" foods or those manure surpluses that are to be exported, biological treatment such as composting or anaerobic digestion with the implicit heating process is the best option. There may be some contention on the significance of the often-stated conditions of $70^{\circ} \mathrm{C}$ for one hour but this is rapidly becoming an established benchmark of treatment. To ensure that any set standards relating to temperature-time conditions are met or exceeded, the provision of a final heating phase to complete the process seems the most reliable approach.

- In the absence of biological treatment, direct thermal treatment of effluents in certain cases may yet prove a viable option if sufficient heat recovery is included in the process design: it would also seem a reasonable alternative to chemical use in the event of the outbreak of a notifiable disease. 


\section{References}

Ackers, M.L., Mahon, B.E., Leahy, E. et al. 1998 An outbreak of Escherichia coli O157 : H7 infections associated with leaf lettuce consumption. Journal of Infectious Diseases, 177 (6), 1588-1593.

Ali, S.H. 2004 A socio-ecological autopsy of the E. coli O157:H7 outbreak in Walkerton, Ontario, Canada. Social Science and Medicine. Volume 58, Issue 12, 2601-2612

Amon, M., Dobeic, M., Sneath, R.W., Phillips, V.R., Misselbrook, T.H., Pain, B.F. 1997. A farm-scale study on the use of clinoptilolite zeolite and De-Odorase ${ }^{\circledR}$ for reducing odour and ammonia emissions from broiler houses. Bioresource Technology, Volume 61, Issue 3, 229-237

Béline, F.; Daumer, M.L.; Guiziou, F. 2004 Biological aerobic treatment of pig slurry in France: nutrient removal efficiency and separation performances. Transactions of the ASAE. Vol 47, No.3, pp 857-864.

Brinton, W.F. 2000 Compost quality standards and guidelines. Woods End Research Laboratory Inc. Report prepared for the New York State Association of Recyclers, USA. December 2000.

Burton, C.H.; Turner, C. 2003 Manure management - treatment strategies for sustainable agriculture; second edition Silsoe Research Institute, Wrest Park, Silsoe, Bedford, UK. 490 pages.

Burton, C.H. 2007 New challenges for environmental protection in terms of intensive animal production. Proceedings of the 13th International Congress in Animal Hygiene, (ISAH) Tartu, Estonia, 17-21 June 2007.

Burton, C.H.; Pourcher, A.M.; DeGuardia, A. 2007. Amélioration des techniques de transformation des produits organiques solides issues des élevages de porcs et destinés au marché - PARTIE F définition des conditions du «couple» température/durée aux fins de l’hygienisation. Study carried out for the Interprofession des fertilisants organiques de l’Ouest. Cemagref, Groupement de Rennes, France.

Cameron, I. 2007 Biogas market comes on strong. Diesel and Gas Turbine Worldwide Volume 39, Issue $5,10-13$

Carton O.T.; Lenehan J.J. 1998 Sustainable Waste Application Management Project (SWAMP). Optimal use of animal slurries for input reduction and protection of the environment in sustainable agricultural systems. AIR-CT 94-1276, Final Report, 1 October 1994 - 30 September 1997 European Commission DG12

Chambers, B.J , Lord, E.I , Nicholson, F.A , Smith, K.A., 1999. Predicting nitrogen availability and losses following application of organic manures to arable land: MANNER Soil Use and Management, volume 15, Issue 3, 137-143

Chambers, B; Nicholson, R.J.; Smith, K,; Pain, B.; Cumby, T.R.; Scotford, I.M. 2001 Managing Livestock Manures. Booklet 1 - making better use of livestock manures on agricultural land. Booklet 2 making better use of manure on grassland. Ministry of Agriculture, Fisheries and Food. Rural and Marine Environment Division, Room 142, Nobel House, 17, Smith Square, London SW1P 3JR

Coté, C., Massé, D., Quessy, S 2006 Reduction of indicator and pathogenic microorganisms by psychrophilic anaerobic digestion in swine slurries. Bioresource Technology Vol 97, Issue 4, 686-691

Cronjé, A.; Turner, C.; Williams, A.G.; Barker, A.; Guy, S. 2003 Composting under controlled conditions. Environmental Technology, Vol 24, 1222-1234.

Cumby, T.R.; Adkin, A.; Burfoot, D.; Burton, C.H.; Keel, P.; Lyne, A.; Munday D.; Parkin, S.; Turner, C.; Williams, S. 2005 Prevention and control of animal diseases: review of decontamination techniques Contract report for DEFRA (SE4001). February 2005, Silsoe Research Institute, Wrest Park, Silsoe, Bedford UK 
DEFRA 2004 Guidance on the treatment in approved composting or biogas plants of animal by products and catering waste. Department for the Environment, Food and Rural Affaires, BSE Division, London, UK; Version 7: December 2004 (amended April 2006).

Desmier, R., 1999. Delving into the matrix. Water, volume 63, 10-11

Eriksen, J.; Sorensen, P. 2006 Slurry acidification, consequences for losses and plant availability of nitrogen and sulphur. Proceedings of the12th international conference of the European Cooperative Research Network on Recycling of Agricultural, Municipal and Industrial residues in Agriculture (RAMIRAN) Aarhus, Denmark, 11-14 September, 2006, 99-102.

Evans, M.R., Donald Ribeiro, C. \& Salmon, R.L. 2003 Hazards of healthy living: bottled water and salad vegetables as risk factors for campylobacter infection. Emerging infectious diseases, 9 (10), 1219-1225.

Groenestein, C.M., den Hartog, L.A., Metz, J.H.M. 2006 Potential Ammonia Emissions from Straw Bedding, Slurry Pit and Concrete Floors in a Group-housing System for Sows. Biosystems Engineering. Volume 95, Issue 2, 235-243

Guan, T.T.Y., Holley, R.A. 2003 Hog manure management, the environment and human health. Kluwer Academic/Plenum Publishers, New York. 168 pages.

Hickman, G.; Chambers, B.; Moore, T. 2005 Managing Farm Manures for Food Safety. Guidelines for Growers to Reduce the Risks of Microbiological Contamination of Read to Eat Crops. Guidance note prepared for the Food Standards Association, London, UK. Final draft, January, 2005.

Jones, P.W 1980 Health hazards associated with the handling of animal wastes. Veterinary Record Volume 106, Issue 1, 4-7

Jones, R., Kelly, L., French, N., England, T., Livesey, C., Wooldridge, M. 2004 Quantitative estimates of the risk of new outbreaks of foot-and-mouth disease as a result of burning pyres. Veterinary Record. Vol 154, Issue 6, 161-165

Lahariya, C., Sharma, A.K., Pradhan, S.K. 2006. Avian flu and possible human pandemic. Indian Pediatrics Volume 43, Issue 4, 317-325

Laszlo, S. 2003. From rivulet to ocean - water: the challenge of the future. Vizugyi Kozlemenyek. Issue $1,73-100$

Levasseur, P.; Dutreme, S. 2007 Hygienisation des effluents d’élevage porcin. Techni Porc. Vol 30, no.2, 3-17.

Mepham, B. 2001. Foot and mouth disease and British agriculture: ethics in a crisis ? Journal of Agricultural and Environmental Ethics. Volume 14, Issue 3, 339-347.

Mitscherlich, E.; Marth, E.H. 1984. Microbial survival in the environment : bacteria and rickettsiae important in human and animal health. Springer-Verlag. Berlin and New York.

Nicholson, F.A., Groves, S.J., Chambers, B.J., 2005. Pathogen survival during livestock manure storage and following land application. Bioresource Technology, volume 96, Issue 2, 135-143

Ondersteijn, C.J.M., Beldman, A.C.G., Daatselaar, C.H.G., Giesen, G.W.J., Huirne, R.B.M. 2002 The Dutch Mineral Accounting System and the European Nitrate Directive: Implications for $\mathrm{N}$ and $\mathrm{P}$ management and farm performance. Agriculture, Ecosystems and Environment. Volume 92, Issue 2-3, 283-296

Scotford, I.M , Cumby, T.R , Richards, P.A., Keppel, D., Lenehan, J.J., 1999. Development of an in-line nutrient sensing system for livestock slurries. Journal of Agricultural and Engineering Research, Volume 74, Issue 3, 303-316

Stacey, K.F.; Parsons, D.A.; Christiansen, K.H.; Burton, C.H. 2007. Assessing the effect of interventions on the risk of cattle and sheep carrying Escherichia coli O157:H7 to the abattoir using a stochastic model 
of the transmission of E.coli O157:H7 on the farm. Preventive Veterinary Medicine, 79 (2007) 32-45

Thompson, D., Muriel, P., Russell, D., Osborne, P., Bromley, A., Rowland, M., Creigh-Tyte, S., Brown, C. 2002. Economic costs of the foot and mouth disease outbreak in the United Kingdom in 2001. OIE Revue Scientifique et Technique, Volume 21, Issue 3, 675-687

Turner, C; Burton, C.H. 1997 The inactivation of viruses in pig slurries: a review. Bioresource Technology 199761 9-20

Turner C.; Williams S.M.; Burton, C.H.; Farrent, J.W.; Wilkinson, P.J. 1998 Laboratory scale inactivation of pig viruses in pig slurry and a design of a pilot plant for thermal inactivation. Water Science \& Technology 38 79-86

Turner C.; Williams S.M.; Burton, C.H.; Cumby, T.R.; Wilkinson, P.J.; Farrent, J.W. 1999 Pilot scale thermal treatment of pig slurry for the inactivation of animal virus pathogens. Journal of Environmental Science and Health Vol B34 (6), 989 -1007

Tyrrel, S.F.; Knox, J.W.; Burton, C.H.; Weatherhead, E.K. 2004 Assuring the microbiological quality of water used to irrigate salad crops: an assessment of the options available. Report no.FV248. February, 2004. Horticultural Research Council. UK.

Vanotti, M.B., Millner, P.D., Hunt, P.G., Ellison, A.Q. 2005 Removal of pathogen and indicator microorganisms from liquid swine manure in multi-step biological and chemical treatment. Bioresource Technology. Volume 96, Issue 2, 209-214

Vanotti, M.B., Szogi, A.A., Hunt, P.G., Millner, P.D., Humenik, F.J. 2007 Development of environmentally superior treatment system to replace anaerobic swine lagoons in the USA. Bioresource Technology. Volume 98, Issue 17, 3184-3194 